\title{
FAKTOR-FAKTOR YANG MEMPENGARUHI KEMANDIRIAN UNTUK BERWIRAUSAHA PADA SISWA SMK
}

\author{
Sri Astuti \\ SMKN 1 Wonosari \\ sastuti.rose@yahoo.com \\ Thomas Sukardi \\ Universitas Negeri Yogyakarta \\ thomkar234@yahoo.co.id
}

\begin{abstract}
Abstrak
Penelitian ini bertujuan untuk mengetahui: (1) memperoleh deskriptif tentang kemandirian siswa, lingkungan keluarga, lingkungan sekolah, dan interaksi teman sebaya pada siswa SMK, (2) mengetahui pengaruh kepribadian, lingkungan keluarga, lingkungan sekolah, dan interaksi teman sebaya baik secara bersama-sama maupun sendiri-sendiri terhadap kemandirian untuk berwirausaha pada siswa SMK, dan (3) mengetahui seberapa besar pengaruh faktor kepribadian, lingkungan keluarga, lingkungan sekolah, dan interaksi teman sebaya secara bersama-sama terhadap kemandirian untuk berwirausaha pada siswa SMK. Penelitian ini merupakan penelitian survey dengan pendekatan ex post facto. Teknik analisis data yang digunakan adalah analisis deskriptif, analisis regresi linier sederhana dan analisis regresi ganda dengan bantuan software SPSS 18. Hasil penelitian menunjukan bahwa: (1) kemandirian untuk berwirausaha tinggi (50,5\%), kepribadian tinggi (73,3\%), lingkungan keluarga tinggi (49,5\%), lingkungan sekolah tinggi $(69,5 \%)$ dan interaksi teman sebaya tinggi $(44,8 \%)$, (2) terdapat pengaruh kepribadian, lingkungan keluarga, lingkungan sekolah, dan interaksi teman sebaya secara sendiri-sendiri maupun bersama-sama terhadap kemandirian siswa untuk berwirausaha, dan (3) sumbangan efektif variabel kepribadian, lingkungan keluarga, lingkungan sekolah, dan interaksi teman sebaya secara bersama-sama terhadap kemandirian untuk berwirausaha $\left(R^{2}\right)$ sebesar 68,6\% dan sumbangan efektif masing-masing variabel yaitu lingkungan keluarga 53,5\%, kepribadian 9,7\%, interaksi teman sebaya 3,9\%, dan lingkungan sekolah 1,6\%.
\end{abstract}

Kata kunci: kemandirian, kewirausahaan

\section{FACTORS INFLUENCE THE AUTONOMY FOR ENTREPRENEURE IN STUDENT'S SMK}

\begin{abstract}
This study aims to uncover: (1) the descriptive abaut autonomy students for entrepreneur, personality, family environment, school environment, and peer relationships at SMK, (2) the influence of personality, family environment, school environment, and peer relationships by together as well as individually for entrepreneurship at SMK, (3) know the influence of personality factors, family environment, school environment, and peer interaction jointly and severally against the autonomy of entrepreneurship in vocational students. This was a survey research with ex post facto approach study. The data were analyzed using the descriptive analysis technique, simple liner regression analysis and multiple regression analysis with the help of software SPSS 18. The result showed: (1) the autonomy for entrepreneur was high (50,5\%), personality was high $(73,3 \%)$, family environment was high (49,5\%), school environment was high (69,5\%) and peer relationship was high $(44,8 \%),(2)$ there are influence of personality factors, family environment, school environtment, and peer relationships with the autonomy for entrepreneurship both individually, and (3) the effect personality factors, family environment, school environment, and peer relationship together against the autonomy for entrepreneurship $\left(R^{2}\right) 68,6 \%$ and the effect of each predictor was 35,5\% family environment, 9,7\% personality, 3,9\% peer relationships, and 1,6\% of school environment.
\end{abstract}

Keywords: autonomy, entrepreneure 


\section{PENDAHULUAN}

Globalisasi dan industrialisasi merupakan sebuah tantangan dan peluang yang harus dapat dimanfaatkan untuk dapat hidup sejajar dan berdampingan dengan negara lain. Globalisasi dan industrialisasi disalah satu sisi membuka peluang untuk mempercepat laju pembangunan, tetapi disisi lain membawa tantangan persaingan yang semakin ketat. Keunggulan kompetitif atas produk dan jasa tentunya menjadi faktor utama yang perlu diperhatikan dan untuk mewujudkan hal tersebut tentunya diperlukan kualitas sumber daya manusia yang unggul. Salah satu upaya untuk meningkatkan kualitas sumber daya manusia adalah melalui jalur pendidikan.

Pendidikan merupakan sektor paling strategis dalam pembangunan nasional, karena melalui pendidikan dapat diberikan bekal pengetahuan, kemampuan dan sikap. Pendidikan yang sesuai untuk menghadapi tantangan globalisasi adalah pendidikan yang berorientasi pada dunia industri dengan pendekatan pembelajaran dan didukung oleh kurikulum yang sesuai. Salah satu lembaga pendidikan tersebut adalah Sekolah Menengah Kejuruan (SMK).

Undang-Undang Republik Indonesia No 20 tahun 2003 tentang Sistem Pendidikan Nasional berbunyi: Pendidikan Kejuruan merupakan pendidikan yang mempersiapkan peserta didik untuk dapat bekerja dalam bidang tertentu atau melanjutkan ke jenjang pendidikan yang lebih tinggi sesuai dengan kompetensinya. Pernyataan di atas mengandung makna bahwa SMK dituntut harus memiliki kemampuan dan ketrampilan yang sesuai dengan keahliannya sehingga setelah lulus diharapkan mereka dapat memasuki dunia kerja sesuai dengan kompetensinya baik bekerja pada perusahaan orang lain maupun membuka usaha sendiri. Dengan demikian keberhasilan dalam penyelenggaraan pendidikan di SMK diukur dari seberapa besar lulusan SMK tersebut dapat terserap ke dunia kerja sehingga pada akhirnya dapat mengurangi jumlah pengangguran.

Data di lapangan menunjukan bahwa jumlah pengangguran terdidik masih tinggi. Adapun data pengangguran dari BPS disajikan pada Tabel 1.
Tabel 1. Data Pengangguran dalam Persen

\begin{tabular}{ccccc}
\hline \multirow{2}{*}{$\begin{array}{c}\text { Pend. } \\
\text { Tertinggi }\end{array}$} & \multicolumn{2}{c}{2010} & \multicolumn{2}{c}{2011} \\
\cline { 2 - 5 } & Feb & Agust & Feb & Agust \\
\hline < SD & 3,71 & 3,81 & 3,37 & 3,56 \\
SMP & 7,55 & 7,45 & 7,83 & 8,37 \\
SMA & 11,90 & 11,90 & 12,17 & 10,66 \\
SMK & 13,81 & 11,87 & 10,00 & 10,43 \\
DIPLOMA & 15,71 & 12,76 & 11,59 & 7,16 \\
UNIVER- & 14,24 & 11,92 & 9,96 & 8,02 \\
SITAS & & & & \\
JUMLAH & 7,41 & 7,14 & 6,80 & 6,56
\end{tabular}

Sumber: BPS, 2012

Data di atas menunjukan bahwa jumlah pengangguran lulusan SMK masih tinggi yaitu dilihat pada bulan Febuari 2010 terdapat 13,81\% bulan Agustus 2010 terdapat 11,87\% bulan Febuari 2011 terdapat 10,00\% dan pada bulan Agustus 2011 terdapat 10,43. Data tersebut apabila dibandingkan dengan tamatan Sekolah Dasar (SD) dan Sekolah Menengah Pertama (SMP) ternyata memiliki persentase yang lebih tinggi. Seperti halnya tingkat pengangguran di DIY jumlah pengangguran mencapai 78.800 orang dari 1,9 juta angkatan kerja (Harian Jogja). Pengangguran tersebut terjadi karena kebanyakan orang masih mengharapkan kerja pada instansi yang tidak memiliki resiko tinggi seperti Pegawai Negeri Sipil (PNS) maupun instansi yang mampu memberikan gaji setiap bulannya, sedangkan untuk pekerjaan yang memiliki resiko tinggi seperti berwirausaha mereka kurang tertarik.

Pernyataan di atas diperkuat dengan adanya data tentang kondisi penduduk di Kabupaten Gunungkidul sesuai dengan status pekerjaannya. Adapun data tersebut dapat dilihat pada Tabel 2.

Berdasarkan data dari Badan Pusat Statistik di Kabupaten Gunungkidul tersebut tampak bahwa penduduk yang memilih bekerja sebagai buruh pada orang lain memiliki persentase yang sangat besar dibandingkan dengan penduduk yang bekerja dengan usaha sendiri seperti berwirausaha 
Tabel 2. Presentase Penduduk 10 Tahun ke Atas Sesuai Status Pekerjaan Utama di Kabupaten Gunungkidul Tahun 2011

\begin{tabular}{clc}
\hline No $\quad$ Status Pekerjaan Utama & Persentase \\
\hline $1 \begin{array}{l}\text { Berusaha sendiri tanpa bantuan } \\
\text { orang lain }\end{array}$ & 11,01 \\
& $\begin{array}{l}\text { Berusaha dengan dibantu } \\
\text { buruh tidak tetap/ buruh tidak } \\
\text { dibayar }\end{array}$ & 30,52 \\
3 & $\begin{array}{l}\text { Berusaha dengan dibantu } \\
\text { buruh tetap/ buruh dibayar }\end{array}$ & 2,48 \\
4 & Buruh/karyawan \\
5 & $\begin{array}{l}\text { Pekerja bebas di pertanian } \\
6\end{array}$ & 1,65 \\
& $\begin{array}{l}\text { Pekerja bebas non pertanian } \\
7\end{array}$ & 7,15 \\
& $\begin{array}{l}\text { Pekerja tidak dibayar/pekerja } \\
\text { keluarga }\end{array}$ & 25,21 \\
& JUMLAH TOTAL & 100,00 \\
\hline
\end{tabular}

Sumber: BPS Gunungkidul, 2012

Data tentang tingginya angka pengangguran terdidik, persentase terbesar penduduk bekerja sebagai buruh dan pegawai rumah tangga serta masih tingginya lulusan SMK yang mencari pekerjaan merupakan bukti bahwa masih kecilnya ketersediaan lapangan pekerjaan bagi mereka.

Berdasarkan pengamatan penulis sebagai guru Busana Butik di Gunungkidul serta beberapa guru Busana Butik yang lainnya, sebenarnya 70\% lebih lulusan SMK Busana Butik langsung terserap ke perusahaan. Akan tetapi kenyataan yang terjadi perusahaanperusahaan tersebut tidak sesuai dengan kompetensi yang mereka miliki seperti perusahaan elektronika di Batam, perusahaan pembuatan kabel di Bogor maupun di Supermarket. Sedangkan siswa yang bekerja pada Garment tidak bertahan lama dengan alasan tertentu. Berdasarkan survei dari beberapa alumni SMKN 1 Wonosari yang berhasil membuka usaha busana sendiri mengaku bahwa mereka senang dengan pilihan pekerjaan mereka. Tetapi dari pengamatan kami lulusan yang memiliki keberanian untuk membuka usaha sendiri tidak lebih dari $10 \%$, dan itupun mereka mencari pengalaman dengan bekerja pada industri lain dahulu baru berani membuka usaha sendiri.
Kenyataan di atas memberikan gambaran bahwa kewirausahaan merupakan salah satu solusi penting untuk mengatasi masalah pengangguran. Harian Seputar Indonesia (Selasa, 4 September 2012) menulis bahwa kewirausahaan dinilai mampu memberikan kontribusi terhadap perekonomian dan mencetak tenaga yang kreatif. Hal ini dikarenakan kewirausahaan merupakan salah satu pilar ekonomi nasional yang tangguh menghadapi krisis ekonomi global sekaligus solusi mengurangi kemiskinan serta menyerap pengangguran. Untuk itu dibutuhkan program pendidikan kewirausahaan bagi siswa untuk memberikan kesempatan belajar kepada mereka agar memperoleh pengetahuan, keterampilan, dan menumbuh kembangkan jiwa kewirausahaan. Peran pendidikan dalam memotivasi para lulusan menjadi young entrepreneurs merupakan salah satu faktor pendorong pertumbuhan kewirausahaan. Siklus yang kemudian terjadi adalah dengan meningkatnya wirausaha dari lulusan SMK maka akan mengurangi pengangguran, serta menambah jumlah lapangan pekerjaan.

Berdasarkan pengamatan memang sebagian besar siswa SMK masih belum memiliki kemandirian yang baik di lingkungan sekolah. Hal ini dapat terlihat ketika proses pembelajaran dimana siswa memiliki ketergantungan yang tinggi terhadap guru. Sebagai contoh dalam materi kejuruan siswa kurang percaya diri untuk melakukan langkah-langkah dalam pembuatan produk tanpa harus bertanya kepada guru pengampunya. Permasalahan inilah yang kemudian harus dipikirkan jalan keluarnya.

Salah satu temuan bagi SMK berdasarkan kenyataan yang terjadi di lapangan adalah tujuan dari pendidikan belum tercapai sepenuhnya. Ketersediaan sarana dan prasarana yang jauh dibawah standar industri menjadi kambing hitam atas penyebab lulusan SMK kurang kompeten dan tidak dapat memenuhi tuntutan industri, padahal dengan jumlah siswa SMK yang lulus pada tiap tahunnya seharusnya dapat terserap langsung ke industri sesuai dengan kompetensinya atau menciptakan lapangan sendiri apabila hal itu tidak terjadi tentunya akan menciptakan pengangguran yang semakin tinggi. Oleh karena itu SMK harus dapat mencari solusi untuk mengatasi permasalahan tersebut dan salah satunya adalah dengan menyiapkan 
peserta didik menjadi pribadi yang mandiri sehingga lulusannya tidak hanya bekerja dengan industri yang sudah ada tetapi bisa menciptakan lapangan sendiri atau berwirausaha.

\section{Sekolah Menengah Kejuruan (SMK)}

Menurut UU no 20 tahun 2003 tentang Sistem Pendidikan Nasional, "pendidikan kejuruan merupakan pendidikan yang mempersiapkan peserta didik untuk dapat bekerja dalam bidang tertentu atau melanjutkan ke jenjang pendidikan yang lebih tinggi sesuai dengan kompetensinya". Pengertian tersebut nampak bahwa tujuan sejak awal penyelenggaraan Sekolah Menengah Kejuruan adalah untuk meningkatkan keterampilan ataupun keahlian siswa sehingga tercipta lulusan yang terampil, profesional dan siap memasuki lapangan pekerjaan atau melanjutkan ke jenjang pendidikan yang lebih tinggi. Pernyataan tersebut sesuai dengan PP no 17 tahun 2010 mengenai fungsi Pendidikan kejuruan yang salah satunya menyebutkan bahwa pendidikan kejuruan membekali peserta didik dengan kemampuan ilmu pengetahuan dan teknologi serta kecakapan kejuruan pada profesi sesuai dengan kebutuhan masyarakat. Penjelasan umum mengenai kecakapan kejuruan/vokasi lebih lanjut dijelaskan bahwa kecakapan kejuruan mencakup kecakapan dalam memilih pekerjaan, mengelola pekerjaan, mengembangkan profesionalitas dan produktifitas kerja dan kode etik bersaing dalam melakukan pekerjaan. Dengan demikian fungsi pendidikan kejuruan adalah untuk meningkatkan daya saing bangsa dan menghasilkan lulusan yang mandiri, bermutu, terampil, ahli dan profesional, maupun belajar sepanjang hayat, serta memiliki kecakapan hidup untuk mem-bantu dirinya dalam menghadapi berbagai tujuan dan perubahan.

Pendapat mengenai pendidikan kejuruan di atas telah tertuang dalam Peraturan Pemerintah Pendidikan Nasional Republik Indonesia nomor 23 Tahun 2006 tentang Standar Nasional Pendidikan didalamnya tercantum mengenai Standar Kompetensi Lulusan pada satuan Pendidikan Menengah Kejuruan bertujuan untuk meningkatkan kecerdasan, pengetahuan, kepribadian, akhlak mulia, serta keterampilan untuk hidup mandiri dan mengikuti pendidikan lebih lanjut sesuai dengan kejuruannya. Tujuan tersebut diperkuat de- ngan salah satu Standar Kompetensi Lulusan SMK, yaitu: "menguasai kompetensi Program Keahlian dan kewirausahaan baik untuk memenuhi tuntutan dunia kerja maupun untuk mengikuti pendidikan tinggi sesuai dengan kejuruannya"(Depdiknas, 2007: 75). Dengan demikian maka lulusan SMK diharapkan selain memiliki kecerdasan, pengetahuan, kepribadian yang mandiri dan akhlak yang mulia tetapi juga harus memiliki keterampilan sehingga memberikan bekal untuk hidup lebih mandiri yaitu dengan bekerja atau membuka usaha sendiri disamping keinginan untuk melanjutkan kejenjang pendidikan yang lebih tinggi.

Depdiknas lebih lanjut menjelaskan karena lulusan SMK dapat bekerja sebagai wiraswasta atau pegawai maka pembelajaran dilaksanakan melalui 2 jalur, yaitu (1) jalur kelas industri, dimana peserta didik belajar disekolah dan berlatih di industri, dan (2) jalur kelas wiraswasta/mandiri, dimana peserta didik belajar dan berlatih berwiraswasta di sekolah dan berusaha mandiri (Depdiknas, 2007: 11)

\section{Kewirausahaan}

Wirausaha menurut Hisrich-Peters (2002: 10), adalah suatu proses atau kegiatan untuk menciptakan/membuat produk yang baru dan berbeda dengan yang lainnya dimana kegiatan tersebut dikerjakan dengan mengorbankan waktu dan tenaga disertai dengan pengorbanan keuangan, psikis, dan resiko sosial untuk mendapatkan penghargaan baik berupa uang/materi, mendapatkan kepuasan, serta kebebasan pribadi.

Menurut Frederick, Kuratko \& Hadgetts (2007: 29) wirausaha diartikan sebagai proses memandang jauh kedepan yang selalu dinamis dengan cara selalu melakukan perubahan dan berkreasi. Dalam melaksanakan perubahan tersebut diperlukan adanya kemampuan untuk memecahkan masalah, kemampuan menghadapi resiko, waktu, karir, kerja sama tim, dan keterampilan sehingga pada akhirnya akan memperoleh kepuasan diri dan kemandirian.

Pengertian tentang wirausaha diatas dapat dimaknai bahwa seorang wirausaha adalah orang yang memiliki semangat, perilaku dan kemampuan untuk menciptakan produk yang baru atau memberikan nilai tambah pada sesuatu yang sudah ada agar memiliki nilai 
jual yang dilakukan untuk mendapatkan keuntungan bagi dirinya sendiri maupun orang lain sehingga tidak tergantung pada orang lain atau memiliki kemandirian.

Mc Clelland dalam Yuyus Suryana dan Kartib Bayu (2010: 40) mengajukan konsep Need for Achievment (N-Ach) yang diartikan sebagai virus kepribadian yang menyebabkan seseorang ingin berbuat baik dan terus maju, selalu berpikir untuk berbuat yang lebih baik, dan memiliki tujuan yang realistis dengan mengambil tindakan resiko yang benar-benar telah diperhitungkan. Adapun karakteristik mereka yang memiliki $\mathrm{N}$-Ach tinggi adalah sebagai berikut:

1. Lebih menyukai pekerjaan dengan resiko yang realistis.

2. Bekerja lebih giat dalam tugas-tugas yang memerlukan kemampuan mental.

3. Tidak bekerja lebih giat karena adanya imbalan uang.

4. Ingin bekerja pada situasi dimana dapat diperoleh pencapaian pribadi (personal Achievment).

5. Menunjukan kinerja yang lebih baik dalam kondisi yang memberikan umpan balik yang jelas positif.

6. Cenderung berpikir ke masa depan serta memiliki pemikiran jangka panjang.

Hisrich \& Peter (2002: 52) menyebutkan bahwa karakteristik wirausaha ada 7, yaitu seorang wirausaha memiliki kemampuan untuk memahami lingkungan, memiliki visi atau pandangan kedepan dan fleksibel/tidak kaku, memiliki kreatifitas dalam pengelolaan usaha, dapat bekerja sama dalam tim, terbuka, dapat membangun kerjasama dalam memajukan perusahaan, dan mampu mempertahankan diri.

\section{Kemandirian}

Salzman dalam Syamsu Yusuf (2007: 184) mengemukakan bahwa remaja merupakan masa perkembangan sikap tergantung (dependence) terhadap orang tua kearah kemandirian (independence), minat-minat seksual, perenungan diri dan perhatian terhadap nilai-nilai estetika dan isu-isu moral. Beberapa tugas perkembangan remaja yang disampaikan oleh Hurlock menjelaskan bahwa kemandirian merupakan salah satu aspek penting bagi remaja untuk menghadapi masa per- kembangan berikutnya yaitu masa dewasa dalam kehidupannya di masyarakat.

Monks,dkk (1994: 279) mengatakan bahwa orang yang mandiri akan memperlihatkan perilaku yang eksploratif, mampu mengambil keputusan, percaya diri dan kreatif. Selain itu juga mampu bertindak kritis, tidak takut berbuat sesuatu, mempunyai kepuasan dalam melakukan aktifitasnya, mampu menerima realita serta dapat memanipulasi lingkungan, berinteraksi dengan teman sebaya, terarah pada tujuan dan mampu mengendalikan diri. Tidak adanya kemandirian pada remaja akan menghasilkan berbagai macam problem perilaku misalnya rendah diri, pemalu, kurang punya motivasi sekolah, kebiasaan belajar yang kurang baik dan perasaan tidak aman dan cemas.

Steinberg dalam Rahayu Ginintasi (2009: 6), menyusun kemandirian dalam 3 aspek, yaitu:

1. Kemandirian Emosi (Emotional Autono$m y$ ), yaitu kemandirian yang merujuk pada pengertian yang dikembangkan anak mengenai individuasi dan melepaskan diri atas ketergantungan mereka dalam pemenuhan kebutuhan-kebutuhan dasar dari orang tua mereka.

2. Kemandirian perilaku (Behavior Autono$m y$ ), yaitu kemandirian dalam perilaku bebas untuk berbuat atau bertindak sendiri tanpa tergantung pada bimbingan orang lain. Kemandirian perilaku merajuk kepada kemampuan seseorang melakukan aktivitas sebagai manifestasi dari berfungsinya kebebasan dengan jelas menyangkut peraturan-peraturan yang wajar mengenai perilaku dan pengambilan keputusan seseorang.

3. Kemandirian nilai (Value Autonomy), yaitu kemandirian yang merujuk pada suatu pengertian mengenai kemampuan seseorang untuk mengambil keputusankeputusan dan menetapkan pilihan yang lebih berpegang pada prinsip-prinsip individual yang dimilikinya dari pada mengambil prinsip-prinsip orang lain.

Ali dan Asrori (2008: 118) menjelaskan bahwa kemandirian dipengaruhi oleh beberapa faktor yang meliputi gen atau keturunan orang tua, pola asuh orang tua, sistem pendidikan di sekolah, dan sistem pendidikan di masyarakat. Genetika atau keturunan merupa- 
kan faktor pertama yang mempengaruhi perkembangan individu. Menurut Syamsu Yusuf (2007: 31) genetika diartikan sebagai totalitas karakteristik individu yang diwariskan orang tua kepada anak atau segala potensi baik fisik maupun psikis yang dimiliki individu sejak masa konsepsi sebagai pewarisan dari pihak orang tua melalui gen-gen. Namun demikian tidak semua material genetika tampak dan dapat diukur melainkan hanya sebagian saja. Material genetika yang tampak dan dapat diamati ini disebut dengan fenotip (Santrock, 2003: 79).

\section{Kepribadian}

Kepribadian diartikan sebagai "keterpaduan antara aspek-aspek kepribadian yang meliputi aspek psikis seperti kecerdasan, bakat, sikap, motif, minat, kemampuan, moral dan aspek jasmaniah seperti postur tubuh, tinggi dan berat badan, indra, dan sebagainya" (Nana Syaodih Sukmadinata, 2004: 136). Mouly (1973: 447) mendefinisikan kepribadian sebagai keseluruhan dari kondisi fisik, mental dan emosional yang menyatu menjadi karakteristik individu yang unik dan khas sehingga memiliki perbedaan dengan individu yang lainnya.

Kepribadian merupakan suatu kesatuan yang menyeluruh dan kompleks. Setiap individu memiliki kepribadian tersendiri, namun meskipun demikian para ahli membuat pengelompokan kepribadian berdasarkan melihat satu atau beberapa faktor dominan, ciriciri utama dan beberapa kesamaan. Srivata (2013) mengatakan bahwa kepribadian seseorang dapat dilihat dari 5 faktor yang mempengaruhinya yaitu:

1. Keterbukaan yang mencakup ciri-ciri kepribadian seperti: cerewet, energik, dan tegas.

2. Keramahan yang mencakup ciri-ciri kepribadian seperti: simpatik, baik hati, dan penuh kasih sayang.

3. Kesadaran yang mencakup ciri-ciri kepribadian seperti: terorganisir, menyeluruh, dan perencanaan.

4. Neurotisme yang mencakup cirri-ciri kepribadian seperti : tegang, murung, dan cemas.

5. Keterbukaan terhadap pengalaman yang mencakup cirri-ciri kepribadian seperti memiliki kepentingan yang luas, imaginatif dan berwawasan.
Kepribadian seseorang tidak persis sama dengan kepribadian orang lain. Menurut Buchari Alma (2007: 78) kepribadian yang mendukung seorang wirausaha adalah kepribadian yang produktif dimana orang tersebut memiliki sifat senang berinteraksi, bergaul, toleransi, terbuka sesama teman, memiliki rasa empati, dan suka menolong orang lain yang membutuhkan pertolongan. Lebih lanjut Buchari menggolongkan kepribadian yang produktif menjadi 3, yaitu kepribadian produktif tinggi, kepribadian produktif rata-rata, dan kepribadian produktif yang rendah. Orang yang berkepribadian tinggi merupakan orang yang memiliki sifat percaya diri, tidak banyak tergantung pada orang lain, memiliki rasa tanggungjawab, obyektif dan kritis, emosinya stabil, sociability. Sedangkan orang yang berkepribadian rendah secara emosional dan mentalnya cacat serta sangat tergantung pada orang lain.

\section{Lingkungan Keluarga}

Hubungan sosial pertama kali dimulai adalah dalam keluarga. Keluarga menurut F.J Brown dalam Syamsu Yusuf (2007: 36) diartikan dalam pengertian luas dan pengertian sempit. Pengertian secara luas keluarga meliputi semua pihak yang ada hubungan darah atau keturunan yang dapat dibandingkan dengan clan atau marga, sedangkan pengertian secara sempit keluarga meliputi orang tua dan anak.

Keluarga memiliki peranan dalam perkembangan individu, Santrock (2003: 175) menjelaskan bahwa perkembangan individu dapat dipengaruhi oleh sifat dasar keluarga, urutan kelahiran, perubahan dalam keluarga, teknik pengasuhan dan konflik orang tuaremaja, Hubungan saudara sekandung, dan perubahan keluarga dalam masyarakat yang selalu berubah. Pendapat yang hampir sama dengan Syamsu Yusuf (2007: 42) bahwa faktor keluarga yang mempengaruhi perkembangan individu meliputi keberfungsian keluarga, pola hubungan orang tua dengan anak, dan kelas sosial atau sosial ekonomi.

Diana Baumrid dalam Santrock (2003: 185) menekankan 3 cara menjadi orang tua yang berhubungan dengan aspek-aspek yang berbeda dalam perilaku sosial remaja. Adapun gaya pengasuhan menurut Diana Baumrid adalah sebagai berikut: 
1. Gaya pengasuhan autoritarian (authoritarian parenting). Gaya pengasuhan ini menurut Diana Baumrid dalam Santrock (2003: 185) diartikan sebagai gaya yang membatasi dan bersifat menghukum yang mendesak remaja untuk mengikuti petunjuk orang tua dan untuk menghormati pekerjaan dan usaha. Orang tua yang bersifat autho-ritarian membuat batasan dan kendali yang tegas terhadap remaja dan hanya melakukan sedikit komunikasi verbal.

2. Gaya pengasuhan authoritarian disebut juga dengan gaya pengasuhan otoritas, dimana orang tua menentukan sendiri aturan-aturan dan batasan-batasan yang mutlak harus dibatasi oleh anak tanpa ada kompromi dan pertimbangan dengan keadaan anak. Perkembangan anak dengan gaya pengasuhan ini biasanya mengarah pada perilaku agresif.

3. Gaya pengasuhan autoritatif (authoritative parenting). Gaya pengasuhan orang tua autoritatif menurut Ana Baumrid dalam Santrock (2003: 186) yaitu orang tua mendorong remaja untuk bebas tetapi tetap memberikan batasan dan mengendalikan tindakan-tindakan mereka. Komunikasi verbal timbal balik bisa berlangsung dengan bebas dan orang tua bersikap hangat dan bersifat membesarkan hati remaja. Gaya pengasuhan ini berkaitan dengan perilaku sosial remaja yang kompeten.

\section{Lingkungan Sekolah}

Hurlock dalam Syamsu Yusuf (2007: 54) mengemukakan bahwa sekolah merupakan faktor penentu bagi perkembangan kepribadian anak baik dalam cara berpikir, bersikap maupun berperilaku. Sekolah berperan sebagai pengganti keluarga dan guru sebagai pengganti orang tua. Dengan demikian maka sekolah sebaiknya berupaya untuk menciptakan iklim yang kondusif yaitu dapat memfasilitasi siswa untuk mencapai tugas perkembangannya baik menyangkut secara manajemennya maupun profesional para personelnya.

Sekolah yang efektif adalah sekolah yang dapat memajukan, meningkatkan atau mengembangkan prestasi akademik, keterampilan sosial, sopan-santun dan keterampilanketerampilan siswa yang memungkinkan siswa dapat melanjutkan ke pendidikan yang lebih tinggi atau bekerja. Dengan demikian sekolah yang efektif dapat dikondisikan dengan sitem manajemen sekolah itu sendiri yang diantaranya meliputi kurikulum sekolah, sarana prasarana, dan guru.

Kurikulum Tingkat Satuan Pendidikan untuk SMK didalamnya terdapat struktur kurikulum secara umum dimana didalamnya berisi tentang komponen dan durasi waktu yang di sediakan dalam proses pembelajaran. Dalam kurikulum SMK salah satu arahan dari perkembangan siswa adalah menuju ke kemandirian siswa dengan dibekali kecakapan kejuruan atau vokasional sehingga setelah lulus nanti siswa memiliki bekal untuk hidup baik dengan bekerja di industri, bekerja sendiri maupun melanjutkan ke pendidikan yang lebih tinggi sesuai dengan keahliannya.

Kurikulum KTSP SMK didalamnya juga terdapat materi kewirausahaan dengan tujuan untuk menumbuhkan jiwa mandiri secara ekonomi pada siswa sehingga diharapkan akan tumbuh jiwa berwirausaha dan pada akhirnya akan tercipta para lulusan yang siap untuk berwirausaha. Dalam pelaksanaannya kewirausahaan ini terbagi menjadi materi teori dan praktik. Materi teori berupa pengetahuan yang diberikan kepada siswa sebagai bekal untuk menjadi seorang wirausaha dan juga materi praktik yang bertujuan untuk melatih keterampilan berwirausaha serta memberikan pengalaman secara langsung bagaimanan cara menjalankan suatu usaha yang sebenarnya. Dalam praktiknya siswa diminta untuk melakukan dagang atau dapat dengan mengelola suatu usaha jasa disekolah.

Keputusan menteri pendidikan dan kebudayaan no 0490/U/1992 bab XII pasal 29 ayat 1 mengatakan bahwa setiap Sekolah menengah kejuruan mengusahakan penyelenggarakan unit produksi. Unit produksi merupakan suatu usaha peningkatan mutu sekolah yang ada. Pada dasarnya sebagai wadah pengelolaan dan peningkatan kemampuan sumber daya sekolah agar dapat memberikan nilai tambah bagi sekolah. Menurut Depdiknas (2004) Unit produksi merupakan suatu usaha incorporated intrapreneur atau suatu wadah kewirausahaan dalam suatu organisasi yangn memerlukan kewenangan kusus dari pimpinan sekolah. Unit produksi dikembangkan dengan prinsip keseimbangan antara aspek akademik dan finansial. 
Sekolah Menengah Kejuruan di Indonesia dalam pelaksanaannya termasuk Pendidikan Kejuruan model sistem ganda dan Pendidikan Kejuruan model school-based-enterprise atau unit produksi. Untuk Pendidikan Kejuruan model sistem ganda semua sekolah telah menerapkannya yaitu dengan mengadakan pembelajaran di industri yang terkait dengan kompetensinya, sedangkan untuk unit produksi meskipun tidak semua sekolah memiliki tetapi sebagian besar dari sekolah kejuruan telah memiliki unit produksi yang sesuai dengan jurusan di sekolah masingmasing.

Aspek lain dari faktor sekolah yang mempengaruhi perkembangan individu selain kurikulum adalah guru. Dalam proses pendidikan atau pembelajaran di sekolah tentunya akan terjalin interaksi antara siswa dengan guru. Interaksi ini sebenarnya adalah interaksi antara 2 kepribadian yang berbeda, yaitu antara guru yang memiliki kepribadian dewasa dengan siswa yang memiliki kepribadian belum dewasa dan baru berkembang menuju kedewasaan. Dalam konteksnya guru memiliki guru memiliki peranan yang penting dalam perkembangan individu siswa, dimana guru berperan sebagai contoh atau teladan bagi siswa, sebagai pendidik atau pengajar dan sebagai pembimbing.

Guru sebagai contoh dan teladan karena semua tingkah laku dan sikap guru disekolah selalu diamati oleh siswa sehingga dalam pembawaannya seorang guru harus memiliki sikap dan tingkah laku yang baik. Sebagai pendidik atau pengajar, guru memiliki tugas untuk mentrasfer atau mengajarkan ilmu kepada siswa sehingga siswa dapat memahami ilmu tersebut dan kemudian mengimplementasikan dalam kehidupan sehari-hari. Dalam mendidik, masing-masing guru memiliki karakteristik yang berbeda antara guru yang satu dengan guru yang lain. Perbedaan ini dapat dalam hal cara pendekatan ke siswa, metode mengajar, cara penyampaiannya yang semua itu pasti akan berimbas pada perkembangan individu siswa termasuk kemandirian siswa. Selain sebagai pendidik guru memiliki tugas sebagai pembimbing yaitu mengarahkan siswa untuk hal-hal yang positif sesuai dengan tingkat perkembangannya. Pengarahan siswa tersebut dapat dalam hal pengarahan minat, bakat maupun bimbingan karier dimana siswa
SMK memang harus sudah diarahkan pada persiapan untuk bekerja.

\section{Interaksi Teman Sebaya}

Ali dan Asrori (2008: 87) sendiri mengartikan interaksi sebagai hubungan timbal balik antara dua orang atau lebih dan masingmasing individu yang terlibat didalamnya memainkan peran secara aktif. Dalam interaksi tidak hanya sekedar hubungan antar pihak-pihak yang terlibat melainkan saling mempengaruhi. Sedangkan menurut Santrock (2003: 219), teman sebaya (peers) adalah anak-anak atau remaja dengan dengan tingkat usia atau tingkat kedewasaan yang sama. Pendapat tersebut seiring dengan hasil penelitian Kandel dalam Syamsu Yusuf (2007: 60) menunjukan bahwa karakteristik persahabatan remaja dipengaruhi oleh kesamaan usia, jenis kelamin, dan ras sedangkan di sekolah interaksi teman sebaya dipengaruhi oleh kesamaan harapan pendidikan, nilai/prestasi belajar, absensi, dan pengerjaan tugas-tugas rumah. Interaksi teman sebaya juga memberikan pengaruh dalam memilih cara berpakaian, hobi, perkumpulan dan kegiatan-kegitan sosial lainnya.

Aspek kepribadian remaja yang berkembang secara menonjol dalam pengalaman berinteraksi dengan teman sebaya (Syamsu Yusuf, 2007: 59) meliputi:

1. Pengetahuan sosial/social cognition, merupakan kemampuan untuk memikirkan tentang pikiran, perasaan, motif, dan tingkah laku dirinya dengan orang lain. Kemampuannya memahami orang lain memungkinkan remaja untuk lebih mampu menjalin hubungan sosial yang lebih baik dengan teman sebaya.

2. Konformitas/conformity, merupakan motif untuk menjadi sama, sesuai, seragam, kebiasaan, hobi atau budaya dengan teman sebayanya. Konformitas muncul ketika individu meniru sikap atau tingkah laku orang lain dikarenakan ada tekanan yang nyata maupun yang dibayangkan mereka (Santrock, 2003: 221).

Syamsu Yusuf (2007: 60) mengatakan bahwa interaksi teman sebaya memberikan kesempatan kepada remaja untuk belajar tentang bagaimana berinteraksi dengan orang lain, mengontrol tingkah laku sosial, mengembangkan keterampilan dan minat yang sesuai 
dengan usia, serta saling bertukar perasaan dan masalah. Lebih lanjut Peter dan Anna Freud mengemukakan bahwa interaksi teman sebaya memiliki kesempatan yang penting untuk memperbaiki kerusakan psikis selama masa kanak-kanak. Interaksi dengan suasana yang hangat dan menarik dapat membantu remaja dalam memperbaiki konsep diri, masalah dan tujuan yang lebih jelas, perasaan berharga, dan perasaan yang optimis tentang masa depan.

\section{METODE}

\section{Jenis dan Desain Penelitian}

Penelitian ini bertujuan menggali informasi tentang kemandirian siswa untuk berwirausaha serta faktor-faktor yang diduga kuat mempengaruhinya yaitu faktor kepribadian, keluarga, sekolah, dan interaksi teman sebaya. Dalam penelitian tidak ada pengendalian atau perlakuan terhadap variabel bebas secara langsung karena peristiwa terjadi, sehingga penelitian ini merupakan penelitian survei dengan pendekatan ex post facto.

\section{Tempat dan Waktu Penelitian}

Penelitian dilaksanakan di SMK baik negeri maupun swasta sekabupaten Gunungkidul. Pengambilan data dilaksanakan dari bulan Maret hingga bulan April 2013.

\section{Populasi dan Sampel Penelitian}

Populasi dalam penelitian ini adalah semua siswa kelas XII SMK Kelompok Pariwisata Kompetensi Keahlian Busana Butik. Pemilihan siswa kelas XII sebagai sumber data penelitian karena siswa kelas XII sudah mendapatkan semua materi produktif baik yang teori maupun praktik. Berdasarkan data yang ada di Kabupaten Gunungkidul terdapat 4 SMK Negeri dan 4 SMK swasta. Dengan melihat luasnya daerah di Kabupaten Gunungkidul serta medan yang tidak mudah untuk menjangkaunya maka kami mengambil populasi sebagai berikut:

Berdasarkan data populasi pada Tabel 5 diketahui bahwa jumlah populasi sebesar 152 siswa. Dalam menentukan sampel agar dapat mewakili, maka peneliti menggunakan teknik proporsional random sampling, dimana masing-masing sekolah dengan jumlah respon- den yang berbeda akan diambil sampelnya berdasarkan proporsi jumlah responden pada masing-masing sekolah tersebut. Untuk mengetahui berapa jumlah responden yang akan digunakan sebagai sampel maka langkah sebelumnya adalah menentukan jumlah sampel terlebih dahulu.

Penentuan jumlah sampel pada penelitian ini, peneliti menggunakan tabel penentuan jumlah sampel yang dikembangkan oleh Isaac dan Michael. Berdasarkan tabel penentuan jumlah sampel yang dikembangkan oleh Isaac dan Michael dengan populasi sebanyak 152 pada taraf 5\% didapatkan sampel sebanyak 105 .

\section{Variabel Penelitian}

Variabel dalam penelitian ini terdiri dari 5 variabel, yaitu 4 variabel bebas dan 1 variabel terikat.

\section{HASIL PENELITIAN DAN PEMBAHASAN}

Hasil uji hipotesis memperlihatkan bahwa seluruh variabel bebas yaitu kepribadian, keluarga, lingkungan sekolah, dan hubungan teman sebaya memiliki pengaruh terhadap variabel terikat atau kemandirian untuk berwirausaha. Hasil diatas menunjukan bahwa dalam meningkatkan kemandirian untuk berwirausaha perlu adanya dukungan dari berbagai faktor, yaitu kepribadian, lingkungan keluarga, lingkungan sekolah, dan hubungan teman sebaya. Secara Deskriptif hasil penelitian ini adalah sebagai berikut:

Tabel 3. Rangkuman Kategori Kecenderungan Variabel dalam Persen

\begin{tabular}{llllll}
\hline & \multicolumn{1}{c}{$\mathrm{Y}$} & $\mathrm{X} 1$ & $\mathrm{X} 2$ & $\mathrm{X} 3$ & $\mathrm{X} 4$ \\
\hline $\begin{array}{l}\text { Sangat } \\
\text { tinggi }\end{array}$ & 45,7 & 18,1 & 50,5 & 24,8 & 14,3 \\
Tinggi & 50,5 & 73,3 & 49,5 & 69,5 & 44,8 \\
$\begin{array}{l}\text { Rendah } \\
\text { Sangat }\end{array}$ & 3,8 & 8,6 & 0 & 5,7 & 39,1 \\
Rendah & 0 & 0 & 0 & 0 & 1,9 \\
\hline
\end{tabular}

Berdasarkan tingkat kecenderungannya, kemandirian siswa untuk berwirausaha memiliki kategori sangat tinggi sebesar 48 siswa atau 45,7\%, kategori tinggi 53 siswa 
atau $50,5 \%$, kategori rendah 4 siswa atau $3,8 \%$ dan kategori sangat rendah sebesar 0 siswa atau $0 \%$. Tingkat kecenderungan kepribadian siswa memiliki kategori sangat tinggi sebesar 19 siswa atau 18,1\%, kategori tinggi 77 siswa atau $73,3 \%$, kategori rendah 9 siswa atau $8,6 \%$, dan kategori sangat rendah sebesar 0 siswa atau $0 \%$. Tingkat kecenderungan dukungan keluarga siswa terhadap kemandirian siswa untuk berwirausaha memiliki kategori sangat tinggi sebesar 53 siswa atau 50,5\%, kategori tinggi 52 siswa atau $49,5 \%$, kategori rendah 0 siswa atau $0 \%$ dan kategori sangat rendah sebesar 0 siswa atau $0 \%$. Tingkat kecenderungan dukungan lingkungan sekolah terhadap kemandirian siswa untuk berwirausaha memiliki kategori sangat tinggi sebesar 26 siswa atau 24,8\%, kategori tinggi 73 siswa atau $69,5 \%$, kategori rendah 6 siswa atau $5,7 \%$, dan kategori sangat rendah sebesar 0 siswa atau $0 \%$. Tingkat kecenderungan dukungan interaksi teman sebaya terhadap kemandirian siswa untuk berwirausaha termasuk dalam kategori sangat tinggi sebesar 15 siswa atau $14,3 \%$, kategori tinggi 47 siswa atau 44,8\%, kategori rendah 41 siswa atau 39\%, dan kategori sangat rendah sebesar 2 siswa atau $1,9 \%$.

Hasil dari uji hipotesis diperoleh bahwa pengaruh kepribadian $\left(\mathrm{X}_{1}\right)$ terhadap kemandirian siswa untuk berwirausaha $(\mathrm{Y})$, dengan menggunakan regresi sederhana didapatkan nilai koefisien korelasi positif sebesar 0,648 nilai signifikansi sebesar $0,001 \quad(p<0,05)$ dan harga R Square $\left(R^{2}\right)$ sebesar 0,42 . Artinya terdapat pengaruh yang positif antara kepribadian dengan kemandirian siswa untuk berwirausaha. Pengaruh kepribadian terhadap kemandirian untuk berwirausaha pada siswa SMK Kelompok Pariwisata Kompetensi Keahlian Busana Butik se-Kabupaten Gunungkidul. Pengaruh dukungan lingkungan keluarga $\left(\mathrm{X}_{2}\right)$ terhadap kemandirian siswa untuk berwirausaha (Y), dengan menggunakan regresi sederhana didapatkan nilai koefisien korelasi positif sebesar (R) 0,0,731 nilai signifikansi sebesar $0,000(p<0,05)$ dan harga $R$ Square $\left(\mathrm{R}^{2}\right)$ sebesar 0,535 . Artinya terdapat pengaruh yang positif antara lingkungan keluarga dengan kemandirian siswa untuk berwirausaha. Pengaruh dukungan lingkungan sekolah $\left(\mathrm{X}_{3}\right)$ terhadap kemandirian siswa untuk berwirausaha $(\mathrm{Y})$, dengan menggunakan regresi sederhana didapatkan nilai koefisien korelasi positif sebesar 0,595 nilai signifikansi sebesar 0,027 $(\mathrm{p}<0,05)$ dan harga $\mathrm{R}$ Square $\left(R^{2}\right)$ sebesar 0,354 . Artinya bahwa terdapat hubungan dan pengaruh yang positif antara lingkungan sekolah dengan kemandirian siswa untuk berwirausaha. Pengaruh interaksi teman sebaya terhadap kemandirian untuk berwirausaha pada siswa SMK Kelompok Pariwisata Kompetensi Keahlian Busana Butik se-Kabupaten Gunungkidul. Pengaruh dukungan interaksi teman sebaya $\left(\mathrm{X}_{4}\right)$ terhadap kemandirian siswa untuk berwirausaha (Y), dengan menggunakan regresi sederhana didapatkan nilai koefisien korelasi (R) positif sebesar 0,407 nilai signifikansi sebesar $0,001(\mathrm{p}<0,05)$ dan harga $R$ Square $\left(R^{2}\right)$ sebesar 0,402 . Artinya bahwa terdapat pengaruh yang positif interaksi teman sebaya dengan kemandirian siswa untuk berwirausaha. Pengaruh kepribadian, lingkungan keluarga, lingkungan sekolah dan interaksi teman sebaya secara bersama-sama terhadap kemandirian untuk berwirausaha pada siswa SMK Kelompok Pariwisata Kompetensi Keahlian se-Kabupaten Gunungkidul. Adapun hasil analisis regresi ganda menunjukkan ada korelasi antara kepribadian $\left(\mathrm{X}_{1}\right)$, keluarga $\left(\mathrm{X}_{2}\right)$ lingkungan sekolah $\left(\mathrm{X}_{3}\right)$ dan interaksi teman sebaya $\left(\mathrm{X}_{4}\right)$ secara bersamasama kemandirian siswa untuk berwirausaha (Y) dimana harga koefisien korelasi (r) sebesar 0,828 dan sumbangan efektif masingmasing variabel Lingkungan keluarga 53,5\%, kepribadian $9,7 \%$, interaksi teman sebaya $3,9 \%$, dan lingkungan sekolah, $6 \%$.

\section{SIMPULAN}

1. Secara deskriptif masing-masing variabel dalam penelitian ini dapat disimpulkan sebagai berikut:

a. Kemandirian untuk berwirausaha pada siswa SMK Kelompok Pariwisata Kompetensi Keahlian Busana Butik se-Kabupaten Gunungkidul termasuk tinggi yaitu $50,5 \%$.

b. Kepribadian untuk berwirausaha pada siswa SMK Kelompok Pariwisata Kompetensi Keahlian Busana Butik se-Kabupaten Gunungkidul termasuk tinggi yaitu 73,3\%.

c. Dukungan lingkungan keluarga untuk berwirausaha pada siswa SMK Kelompok Pariwisata Kompetensi Keahlian Busana Butik se-Kabupa- 
ten Gunungkidul termasuk tinggi yaitu $49,5 \%$.

d. Dukungan lingkungan sekolah untuk berwirausaha pada siswa SMK Kelompok Pariwisata Kompetensi Keahlian Busana Butik se-Kabupaten Gunungkidul termasuk tinggi yaitu $69,5 \%$

e. Interaksi teman sebaya siswa pada SMK Kelompok Pariwisata Kompetensi Keahlian Busana Butik seKabupaten Gunungkidul termasuk tinggi yaitu $44,8 \%$.

2. Berdasarkan hasil uji hipotesis maka dapat disimpulkan sebagai berikut:

a. Terdapat pengaruh faktor kepribadian terhadap kemandirian untuk berwirausaha pada siswa SMK Kelompok Pariwisata Kompetensi Keahlian Busana Butik se-Kabupaten Gunungkidul dengan nilai koefisien korelasi (r) adalah 0,648 dan nilai koefisien determinasi $\left(\mathrm{R}^{2}\right)$ adalah 0,420 .

b. Terdapat pengaruh faktor lingkungan keluarga terhadap kemandirian untuk berwirausaha pada siswa SMK Kelompok Pariwisata Kompetensi Keahlian Busana Butik seKabupaten Gunungkidul dengan nilai koefisien korelasi (r) adalah 0,731 dan nilai koefisien determinasi $\left(\mathrm{R}^{2}\right)$ adalah 0,535 .

c. Terdapat pengaruh faktor lingkungan sekolah terhadap kemandirian untuk berwirausaha pada siswa SMK Kelompok Pariwisata Kompetensi Keahlian Busana Butik seKabupaten Gunungkidul dengan nilai koefisien korelasi (r) adalah 0,595 dan nilai koefisien determinasi $\left(\mathrm{R}^{2}\right)$ adalah 0,354 .

d. Terdapat pengaruh faktor interaksi teman sebaya dengan kemandirian untuk berwirausaha pada siswa SMK Kelompok Pariwisata Kompetensi Keahlian Busana Butik seKabupaten Gunungkidul dengan nilai koefisien korelasi (r) adalah 0,638 dan nilai koefisien determinasi $\left(\mathrm{R}^{2}\right)$ adalah 0,407 .

e. Terdapat pengaruh faktor kepribadian, lingkungan keluarga, lingkungan sekolah dan interaksi teman se- baya secara bersama-sama terhadap kemandirian untuk berwirausaha pada siswa SMK Kelompok Pariwisata Kompetensi Keahlian Busana Butik se-Kabupaten Gunungkidul dengan nilai koefisien korelasi (r) adalah 0,828 dan nilai koefisien determinasi $\left(\mathrm{R}^{2}\right)$ adalah 0,686 .

3. Sumbangan variabel kepribadian, lingkungan keluarga, lingkungan sekolah, dan interaksi teman sebaya secara bersama-sama terhadap kemandirian untuk berwirausaha pada siswa SMK Kelompok Pariwisata Kompetensi Keahlian busana butik se-Kabupaten Gunungkidul sebesar $68,6 \%$ dan sumbangan efektif masing-masing variabel yaitu Lingkungan keluarga 53,5\%, kepribadian 9,7\%, interaksi teman sebaya $3,9 \%$, dan lingkungan sekolah, $6 \%$.

\section{Implikasi}

Hasil penelitian menunjukan bahwa faktor-faktor kepribadian, lingkungan keluarga, lingkungan sekolah, dan interaksi/hubungan teman sebaya memberikan pengaruh yang positif dan signifikan terhadap kemandirian siswa untuk berwirausaha. Dengan demikian maka perlu adanya kerja sama antara faktor kepribadian, lingkungan keluarga, lingkungan sekolah, dan interaksi/hubungan teman sebaya dalam upaya meningkatkan kemandirian siswa untuk berwirausaha.

\section{Saran}

Berdasarkan hasil penelitian ada beberapa saran yang perlu dikemukakan sebagai berikut:

1. Kemandirian siswa kelas XII untuk berwirausaha pada SMK Kelompok Pariwisata Program Keahlian Busana Butik se-Kabupaten Gunungkidul perlu ditingkatkan untuk mengurangi jumlah pengangguran akibat dari kurang terserapnya para lulusan ke perusahaan maupun instansi pemerintah. Upaya peningkatan kemandirian siswa untuk berwirausaha dapat diupayakan dengan adanya dukungan dan kerja sama antara kepribadian, lingkungan keluarga, lingkungan sekolah, dan interaksi/hubungan teman sebaya. 
2. Kepribadian yang produktif pada siswa hendaknya dapat ditingkatkan dengan cara memberikan dorongan dan stimulasi dari lingkungan berupa pemberian bekal ketrampilan yang sesuai dengan kompetensinya, mengarahkan keterampilan yang telah dimiliki untuk hal-hal yang dapat menghasilkan uang sehingga kompetensi dapat diakui oleh orang lain, menumbuhkan rasa percaya diri dengan cara selalu memberi dukungan dan penghargaan terhadap kreatifitas yang telah dilakukan, serta melatih siswa untuk berpikir objektif, tenang, dan dapat menerima orang lain sebagai bagian untuk kemajuan dirinya.

3. Lingkungan keluarga perlu dikondisikan lagi agar dapat mendukung kemandirian siswa untuk berwirausaha. Usaha tersebut dapat dilakukan dengan cara Orang tua yang memberikan kebebasan terhadap anak untuk berkreasi dan mengambil keputusan sendiri dengan tetap memberikan arahan, bimbingan, motivasi serta penghargaan yang baik, menumbuhkan kematangan emosional dan rasa percaya diri, selalu menanamkan kemandirian kepada anak-anaknya ketika menghadapi suatu masalah atau ketika menghadapi pekerjaan.

4. Lingkungan sekolah perlu dikondisikan agar dapat meningkatkan kemandirian siswa untuk berwirausaha. Usaha tersebut sebaiknya dilakukan dengan cara menciptakan pembelajaran yang mengarahkan siswa dapat mandiri, percaya diri, dengan diberikan kebebasan berkreasi untuk mengembangkan karya-karya inovatif. Untuk itu hendaknya perlu adanya kerjasama yang saling mendukung dari kurikulum yang mengarah untuk menumbuhkan kemandirian siswa berwirausaha, Guru dalam mengimplementasikan kurikulum, kebijakan manajemen sekolah, serta siswa itu sendiri.

5. Interaksi/hubungan teman sebaya memberikan pengaruh yang cukup besar dalam menumbuhkan kemandirian siswa berwirausaha. Untuk itu sebaiknya siswa lebih selektif dalam memilih kelompok teman sebaya yaitu yang memberikan pengaruh positif bagi kehidupannya. Agar hal itu dapat terwujud tentunya perlu adanya kerjasama antara lingkung- an keluarga dan lingkungan sekolah untuk mengarahkan siswa dalam memilih teman yang baik.

\section{DAFTAR PUSTAKA}

Ali \& Asrori. (2008). Psikologi remaja: perkembangan peserta didik. Jakarta: PT. Bumi Aksara.

Alma, Buchari. (2009). Kewirausahaan. Bandung: Alfabeta.

Badan Pusat Statistik. (2012). Berita resmi statistik. Yogyakarta: BPS Provinsi DIY

Badan Pusat Statistik Kabupaten Gunungkidul. (2012). Gunungkidul dalam angka 2012. Gunungkidul: BPS Kabupaten Gunungkidul.

Departemen Pendidikan Nasional. (2007). Materi sosialisasi dan pelatihan kurikulum tingkat satuan pendidikan (KTSP) $S M K$. Jakarta: Departemen Pendidikan nasional.

Depdiknas. (2010), PeraturanPemerintah RI nomor 17, Tahun 2010, Tentang Pengelolaan dan Penyelenggaraan Pendidikan.

Frederick, H.H, Kuratko, D. F \& Hodgetss, RM. (2007). Entrepreneurship: theory, process, practice. Australia: Nelson Australia Pty Limited.

Ginintasi, Rahayu. (2009). Kontribusi pola pengasuhan orang tua terhadap perkembangan kemandirian dan kreativitas anak. Makalah. Bandung : FIP-Universitas Pendidikan Indonesia.

Hisrich, R. D, Peters, M. P, \& Shepheid, D. A. (2008). Entrepreneurship (International ed.). New York: MC.Graw Hill .

Kewirausahaan perlu ditingkatkan. (4 September 2012). Harian Seputar Indonesia.

Mendiknas. (2006). Peraturan Menteri Pendidikan Nasional RI nomor 23, tahun 2006, tentang standar kompetensi lulusan untuk Pendidikan Dasar dan Menengah. 
Monks, dkk. (1994). Psikologi perkembangan: pengantar dalam berbagai bagian. Yogyakarta: Gadjah Mada University Press.

Mouly G. J. (1973). Psychology for effective teaching. New York: Rinehart and Winston, Inc.

Santrock, J. W. (2003). Adolescence: perkembangan remaja edisi ke-6. (Terjemahan Shinto B.Adelar \& Saragih). Time Mirror Higher Education. (Buku Asli di Terbitkan Tahun 1996).

(2007). Child development: Perkembangan anak edisi ke-11. (terjemahan Mila Ratnawati \& Anna Kuswanti). New York: Mc.Graw-Hill Companies. Inc. (buku Asli di Terbitkan Tahun 2007)
Srivata, S. (2013). Measuring the big five personality factors. Diambil pada tanggal 11 Maret 2013 jam 14:46, dari: http://www.carleton.ca/ tpychyl/01138 2000/BigFive.html

Sukmadinata, N. S. (2004). Landasan psikologi proses pendidikan. Bandung: PT. Remaja Rosdakarya.

Suryana, Y. \& Bayu, K. (2010). Kewirausahaan: pendekatan karakteristik wirausaha sukses. Jakarta: Kencana Prenada Media Group.

Syamsu Yusuf. (2006). Psikologi Perkembangan Anak dan Remaja. Bandung: P. T. Remaja Rosdakarya.

Undang-Undang RI No 20. (2003). UndangUndang Sistem Pendidikan Nasional. Jakarta: Sinar Grafika. 